\title{
Effect of Application of Granular Organic Fertilizer Enriched with Boiler Ash and Neem Leaves Powder on Plant Resistance Against Insect Pests
}

\author{
R. R. Rukmowati Brotodjojo*, Dyah Arbiwati \\ Faculty of Agriculture Universitas Pembangunan Nasional "Veteran” Yogyakarta, Jl. SWK 104 Condong Catur, \\ Yogyakarta, Indonesia. \\ * Corresponding author. E-mail: brotodjojo@upnyk.ac.id \\ Manuscript submitted June 12, 2016; accepted August 18, 2016. \\ doi: 10.17706/ijbbb.2016.6.4.152-157
}

\begin{abstract}
Plant nutrition status could affect plant resistance against insect pests. This researched aimed to study the effect of application of granular organic fertilizer enriched with boiler ash and neem leaves powder on plant resistance against insect pests. Treatment used is kind of organic fertilizer granules $(A, B, C)$ of own products applied with various doses (10 tons/ha, 20 tons/ha, 30 tons/ha). For comparison is a control that uses inorganic fertilizers (Urea $60 \mathrm{~kg} / \mathrm{ha}$; TSP $95 \mathrm{~kg} / \mathrm{ha} ; \mathrm{KCl} 50 \mathrm{~kg} / \mathrm{ha}$ ). Plant tested were caysim against Crocidolomiapavonana larvae and Aphids sp. as well as potato against Lepidiota stigma larvae. The use of fertilizers 10-30 tons/ha can be slightly depressed L. stigma feeding. Lepidiota stigma larvae on unfertilized soil consumed more potato tuber than that of the fertilized soil. Caysim treated with inorganic fertilizers suffered more damaged caused by $C$. pavonana that that treated with granular organic fertilizer. Population of Aphids sp. on Caysim treated with inorganic fertilizers were higher than that that treated with granular organic fertilizer. Organic fertilizer can increase plant resistance against pest.
\end{abstract}

Key words: Granular organic fertilizer, plant resistance, insect pests.

\section{Introduction}

Conventional intensive cultivation put more emphasis on the use of inorganic fertilizers as a source of plant nutrients and synthetic pesticides to suppress pests attack. However, the use of inorganic fertilizers, especially nitrogen fertilizers, continuously in the long term without a balanced use of organic materials can have a negative impact on the physical and chemical properties of the soil. Decline in soil physical properties is indicated by soil compaction and porosity reduction. Decline in soil chemical properties is shown by reduced soil fertility and content of essential micro nutrients in the soil, which in turn will lower crop yields [1]. In addition, the use of synthetic pesticides less wise it will cause an explosion of pests due to the emergence of pest resistance to pesticides and death of natural enemies of pests.

To overcome the adverse effects of conventional farming on the environment and health, the then switch back to organic farming. Organic farming is a cultivation technique by utilizing organic fertilizer as a source of plant nutrients and avoiding the use of inorganic fertilizers and synthetic chemicals for pest control. Proper fertilization may accelerate and strengthen the growth and development of plants, add resistance to certain pests and diseases, as well as improve the quality and quantity of agricultural product. The positive impact of organic fertilizer seen in the short term and long term, which increase soil fertility and crop yields 
[2], [3].

Agricultural waste and other organic materials can be used to add nutrients and processed into organic fertilizer. Organic material derived from livestock and fishery waste can be made into organic fertilizer and supply of macro nutrients N, P, and K in amounts high enough, ie 1.5\% N, 1.5\% P205 1.2\% K20 in the dirt cows and 7-10\% N, 1-3\% P205 in dry fish waste [4], [5]. Boiler ash is agricultural waste which is the residue of bagasse combustion produced in sugar production process. The boiler ash contains $71 \% \mathrm{SiO} 2 ; 3 \%$ P2O5; 8.2\% K20; 3.4\% CaO and some micronutrients (0.2\% Mn0; 1.9\% Al203, 7.8\% and 0.3\% Fe2O3 Mg0) so as to increase the nutrient content of the soil when applied together with the manure [6].

Boiler ash provide a positive influence for the plant through two things: the indirect influence on the soil by improving the availability of $\mathrm{P}$ and a direct influence on the plant, such as improving the efficiency of photosynthesis, induces resistance to biotic and abiotic stresses such as pests and diseases, poisoning $\mathrm{Fe}, \mathrm{Al}$, and $\mathrm{Mn}$, reducing the collapse and fix erectness (erectness) leaves and stems, as well as improve the efficiency of water use. Improved crop yields are mostly due to the increase in the quantity and quality of results. This indicates that $\mathrm{Si}$ improve the efficiency of plant photosynthesis. Giving Si (silicates) causes the leaves to grow stronger and can stretch well, so that it can reduce the negative impact of mutual shading. Silicate that there will improve plant resistance to pests and diseases [7].

Neem is one of the plants that can be used as a pesticide plant. Neem contains azadirachtin, an active ingredient that is toxic against insects. The active ingredient in the seeds is higher than in the leaves [8]. Extracts of neem seed hinder eating and cause death of Plutellaxylostella L. caterpillars 72 hours after application [9]. Previous study indicated that neem seeds extract application and neem leaves used as mulch were effective for controlling Cylasformicarius(Fabricius) on sweet potato [10]. Azadirachtin and neem oil increased mortality of Aphis glycines Matsumura nymphs and prolonged the developmental of surviving insects [11]. The active ingredients contained in neem are systemic, that can be absorbed and translocated throughout the plant. The production of seeds is fewer than leaves, therefore, use the leaves as a botanical pesticide is more easily to be done. Based on these results, this research was conducted to study the effect of neem leaves powder and boiler ash incorporated into granular organic fertilizer to improve plant resistance against insect pests.

\section{Materials and Methods}

\subsection{Grub Geeding Capacity}

The study was conducted at the Plant Protection Laboratory, UPN "Veteran" Yogyakarta, Indonesia (t: $27 \pm 1^{\circ} \mathrm{C}$; RH: $85 \%$ ). This test was conducted to determine the effectiveness of organic fertilizer granules enriched with boiler ash and neem leaf powder in affecting feeding capacity of grubLepidiota stigma. Grub is pest that lives in the soil and causes damage by eating the plant roots. For the experiment, third instar of Lepidiota stigma F. larvae were fed with a slice of potato tuber. Experiments were carried out with 10 treatments and each consists of three replications with ten samples. The treatments were types of own product granular organic fertilizer, i.e. fertilizer A, B and C, each with a dose of 10 tons/ha, 20 tons/ha, 30 tons/ha. As a control was soil without fertilizer. Soil and fertilizer were mixed and placed in a plastic container (Diameter: $7 \mathrm{~cm}$; Height: $10 \mathrm{~cm}$ ). A third instar of L. stigma and a slice of potato were introduced in the middle of the soil, so it was covered by the soil. Soil humidity was kept about $75 \%$. Feeding capacity observations were made for seven days. Feeding capacity was calculated by weighing the potato slice before eating and 24 hours later.

\subsection{Chinese Cabbage Resistance Against Pests}

The study was conducted at the experimental farm of the Faculty of Agriculture Universitas 
Pembangunan Nasional "Veteran" Yogyakarta, CondongCatur. Chinese cabbage/Choy sum (Brassica chinensis var. parachinensis) were planted in polybags with treatment according to the experimental design and put under paranet. The experiment was arranged in a Randomized Completely Block Design (RCBD), each treatment consisted of 10 plants and repeated 3 times. The treatments were the use of a wide variety of granular organic fertilizer enriched with boiler ash and neem leaf powder with various doses (nutrient content can be seen in Table 1). Types of organic fertilizer granules were fertilizer A, B and C, each with a dose of 10 tons/ha, 20 tons/ha, 30 t0ns/ha. As a control was application of inorganic fertilizers (Urea 60 $\mathrm{kg} / \mathrm{ha}$; TSP $95 \mathrm{~kg} / \mathrm{ha}$; KCl $50 \mathrm{~kg} / \mathrm{ha}$ ). During 42 days, observation was conducted every week to observed level of crop damage due to natural infestation of Crocidolomiapavonana (Fabricius).

Table 1. Nutrient Contents of Granular Organic Fertilizers

\begin{tabular}{cccc}
\hline \multirow{2}{*}{ Nutrient } & \multicolumn{3}{c}{ Nutrient contents (\%) } \\
\cline { 2 - 4 } & Fertilizer A & Fertilizer B & Fertilizer C \\
\hline Ca & 3,24 & 2,84 & 1,66 \\
Mg & 0,33 & 0,35 & 0,27 \\
K20 & 1,63 & 1,51 & 1,09 \\
P205 & 0,97 & 1,45 & 1,24 \\
Si & 1,61 & 1,86 & 0,88 \\
& &
\end{tabular}

\subsection{Data Analysis}

Observation data were analyzed using SPSS for Windows version 15. Percentage data were transformed into Arcsin $\sqrt{x}+1$ before being analyzed. All data were analyzed using a one way ANOVA. All multiple comparison tests for means were performed using Duncan Multiple Range Tests.

\section{Results and Discussion}

\subsection{Grub Feeding Capacity}

Feeding capacity was calculated by weighing the weight of the potatoes before given to grub and after consumed daily for seven days. Data on grub feeding capacity can be seen in Fig. 1. The feeding capacity of third instar of L. stigma for seven days fluctuated. The use of granular organic fertilizers 10-30 tons/ha could only slightly depress grub feeding capacity. Grubs introduced into unfertilized consumed more potato than those introduced into fertilized soil. The granular organic fertilizer used was enriched with neem leaves powder that has anti feedant properties [8]. Neem can also function as a natural soil conditioner that helps improve the quality of soil, but also prevents plants from being attacked by certain insect pests [12]. Neem leaves powder was proved to have insecticidal properties on various insects, including Macrotermes spp., Phaseouslus spp., Periplaneta spp. and larvae of Anopheles spp [13].

\subsection{Chinese Cabbage Resistance Against Pests}

Natural infestation of C. pavonana on Chinese cabbage (Choy sum) was started on three weeks after transplanting (Table 2). The damage of Chinese cabbage leaves treated with inorganic fertilizer or 10 tons/ha granular organic fertilizer enriched with neem leaves powder and boiler ash was significantly higher than that of plant fertilized with 30 tons/ha granular organic fertilizer (Table 2).

The results suggest that neem leaves powder and boiler ash can increase plant resistance to insect attack. Azadirachtin content in neem leaves works as antifeedant and repellent against insects [8], [14]-[16]. In some Lepidoptera larvae Azadirachtin stimulate repellent nerves in the maxillary sensilastyloconic thus hampering the feeding of the larvae [15]. Besides the Si content of plants is also hampering the feeding of the larvae. In sugarcane content of crystalline Si in leaf and stem epidermis tissue will increase plant 
resistance to borer attack. The mouthpart of young larvae will be damaged if they consume plant containing crystalline $\mathrm{Si}$ [17]. Other study has shown that the high silica content in rice leaf epidermal tissue is very effective to increase resistance to insect pests [18].

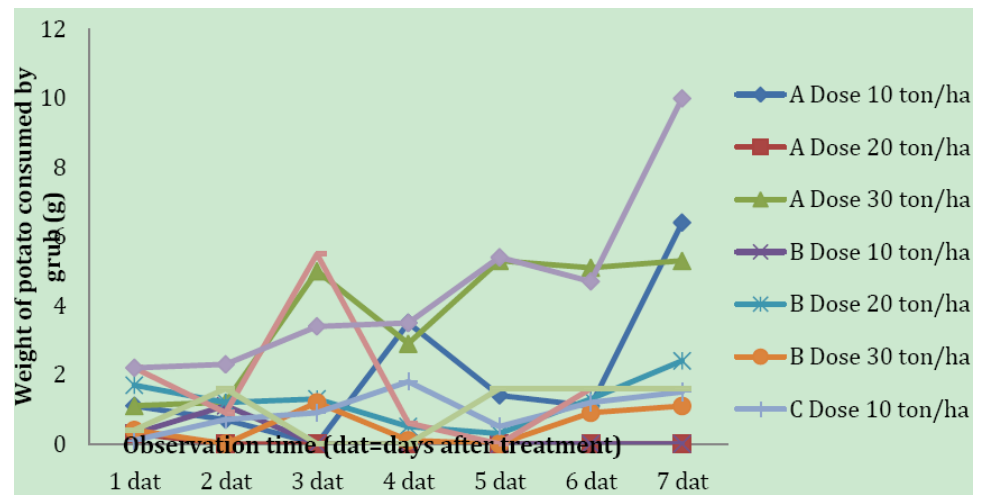

Fig. 1. Weight potatoes consumed by grub (g) for 7 days after treatment (dat).

Table 2. Chinese Cabbageleaves Damage (\%)by Crocidolomia pavonanaon 1-6 Weeks after Transplanting (wat)

\begin{tabular}{cllllll}
\hline Fertilizer & 1 wat & 2 wat & 3 wat & 4 wat & 5 wat & 6 wat \\
\hline A Dose 10 ton/ha & $0,0 \pm 0,0$ & $0,0 \pm 0,0$ & $13,3 \pm 8,3 \mathrm{~b}$ & $13,3 \pm 8,3 \mathrm{~b}$ & $13,3 \pm 8,3 \mathrm{~b}$ & $13,3 \pm 8,3 \mathrm{~b}$ \\
A Dose 20 ton/ha & $0,0 \pm 0,0$ & $0,0 \pm 0,0$ & $0,0 \pm 0,0 \mathrm{a}$ & $0,0 \pm 0,0 \mathrm{a}$ & $0,0 \pm 0,0 \mathrm{a}$ & $0,0 \pm 0,0 \mathrm{a}$ \\
A Dose 30 ton/ha & $0,0 \pm 0,0$ & $0,0 \pm 0,0$ & $0,0 \pm 0,0 \mathrm{a}$ & $0,0 \pm 0,0 \mathrm{a}$ & $0,0 \pm 0,0 \mathrm{a}$ & $0,0 \pm 0,0 \mathrm{a}$ \\
B Dose 10 ton/ha & $0,0 \pm 0,0$ & $0,0 \pm 0,0$ & $43,3 \pm 6,7 \mathrm{c}$ & $43,3 \pm 6,7 \mathrm{c}$ & $60,0 \pm 15,0 \mathrm{c}$ & $75,0 \pm 0,0 \mathrm{c}$ \\
B Dose 20 ton/ha & $0,0 \pm 0,0$ & $0,0 \pm 0,0$ & $1,7 \pm 1,7 \mathrm{a}$ & $1,7 \pm 1,7 \mathrm{a}$ & $1,7 \pm 1,7 \mathrm{a}$ & $1,7 \pm 1,7 \mathrm{a}$ \\
B Dose 30 ton/ha & $0,0 \pm 0,0$ & $0,0 \pm 0,0$ & $1,7 \pm 1,7 \mathrm{a}$ & $1,7 \pm 1,7 \mathrm{a}$ & $1,7 \pm 1,7 \mathrm{a}$ & $1,7 \pm 1,7 \mathrm{a}$ \\
C Dose 10 ton/ha & $0,0 \pm 0,0$ & $0,0 \pm 0,0$ & $33,3 \pm 16,7 \mathrm{c}$ & $33,3 \pm 16,7 \mathrm{c}$ & $33,3 \pm 16,7 \mathrm{~b}$ & $33,3 \pm 16,7 \mathrm{~b}$ \\
C Dose 20 ton/ha & $0,0 \pm 0,0$ & $0,0 \pm 0,0$ & $75,0 \pm 0,0 \mathrm{~d}$ & $75,0 \pm 0,0 \mathrm{~d}$ & $75,0 \pm 0,0 \mathrm{c}$ & $75,0 \pm 0,0 \mathrm{c}$ \\
C Dose 30 ton/ha & $0,0 \pm 0,0$ & $0,0 \pm 0,0$ & $0,0 \pm 0,0 \mathrm{a}$ & $0,0 \pm 0,0 \mathrm{a}$ & $0,0 \pm 0,0 \mathrm{a}$ & $0,0 \pm 0,0 \mathrm{a}$ \\
Control (inorganic & & & & & & \\
fertilizer) & $0,0 \pm 0,0$ & $0,0 \pm 0,0$ & $31,7 \pm 13,6 \mathrm{bc}$ & $31,7 \pm 13,6 \mathrm{bc}$ & $75,0 \pm 0,0 \mathrm{c}$ & $75,0 \pm 0,0 \mathrm{c}$ \\
\hline
\end{tabular}

Means in the same column followed by the same letters are not significantly different $(\mathrm{P}<0.05)$, according toDuncan's test.

Table 3. The Number of Aphids Infested on Chinese Cabbage on 6-13 Weeks after Transplanting (wat)

\begin{tabular}{ccccc} 
Fertilizer & 6 wat & 11 wat & 12 wat & 13 wat \\
\hline A Dose 10 ton/ha & $30,0 \pm 12,5 \mathrm{~b}$ & $13,3 \pm 1.7 \mathrm{a}$ & $8,7 \pm 2.0 \mathrm{a}$ & $4,3 \pm 0.9 \mathrm{a}$ \\
A Dose 20 ton/ha & $1,5 \pm 0,6 \mathrm{a}$ & $6,7 \pm 1.7 \mathrm{a}$ & $9,3 \pm 2.8 \mathrm{a}$ & $9.0 \pm 2.1 \mathrm{~b}$ \\
A Dose 30 ton/ha & $32,3 \pm 12,4 \mathrm{~b}$ & $0,7 \pm 0.7 \mathrm{a}$ & $1,3 \pm 1.3 \mathrm{a}$ & $1,7 \pm 0.9 \mathrm{a}$ \\
B Dose 10 ton/ha & $2,2 \pm 0,6 \mathrm{a}$ & $4,3 \pm 0.7 \mathrm{a}$ & $5,3 \pm 0.3 \mathrm{a}$ & $4,3 \pm 1.2 \mathrm{a}$ \\
B Dose 20 ton/ha & $3,3 \pm 0,6 \mathrm{a}$ & $5,3 \pm 2.3 \mathrm{a}$ & $7,3 \pm 3.9 \mathrm{a}$ & $5,3 \pm 3.5 \mathrm{a}$ \\
B Dose 30 ton/ha & $0,6 \pm 0,4 \mathrm{a}$ & $1,7 \pm 0.9 \mathrm{a}$ & $1,7 \pm 0.3 \mathrm{a}$ & $4.0 \pm 0.6 \mathrm{a}$ \\
C Dose 10 ton/ha & $22,2 \pm 4,3 \mathrm{ab}$ & $18,3 \pm 6.0 \mathrm{~b}$ & $22,3 \pm 8.9 \mathrm{~b}$ & $10.0 \pm 3.2 \mathrm{~b}$ \\
C Dose 20 ton/ha & $7,9 \pm 1,8 \mathrm{a}$ & $24.0 \pm 13.0 \mathrm{~b}$ & $28,7 \pm 13.2 \mathrm{~b}$ & $16,7 \pm 1.7 \mathrm{~b}$ \\
C Dose 30 ton/ha & $3,2 \pm 1,2 \mathrm{a}$ & $3,3 \pm 1.9 \mathrm{a}$ & $2,7 \pm 0.9 \mathrm{a}$ & $2,7 \pm 1.5 \mathrm{a}$ \\
Control (inorganic & & & & \\
fertilizer) & $90,0 \pm 9,8 \mathrm{c}$ & $20.0 \pm 5.0 \mathrm{~b}$ & $21.0 \pm 4.0 \mathrm{~b}$ & $15.0 \pm 2.0 \mathrm{~b}$ \\
\hline
\end{tabular}

Means in the same column followed by the same letters are not significantly different $(\mathrm{P}<0.05)$, according toDuncan's test. 
The number of Aphids attacked Chinese cabbage was higher on plants treated with inorganic fertilizer (control) than on plants treated with organic fertilizer on six weeks after transplanting. However, on 11-13 weeks after transplanting the number of Aphids on Control plant was not significantly different from plants treated with Fertilizer C 10 ton/ha or 20 ton/ha (Table 3). The results indicated that inorganic fertilizer decreased Chinese cabbage resistance against Aphids, especially on young plants ( 6 wat). In comparison to organic fertilizer, inorganic fertilizer contains more nitrogen that make plant cell contains more water favored by sucking insects. Previous study showed that infestation of aphids (Rhopalosiphummaidis) on corn in fields treated with organic fertilizer for at least 2 years was lower than corn treated with synthetic fertilizer [19]. It is suggested that nitrogen stimulates insect reproduction. Other study showed that fecundity and developmental rates of the green peach aphid, Myzuspersicae increased as levels of soluble $\mathrm{N}$ in leaf tissue increased [20].

\section{Acknowledgment}

The author would like to thank the Ministry of Research, Technology and Higher Education that has provided research funding through competitive grants scheme, Letter of Assignment Number: ST/30/IV/2015/LPPM.

\section{References}

[1] Zhang, H., Wang, B., \& Xu, M. (2008). Effects of inorganic fertilizer inputs on grain yields and soil properties in a long-term wheat-corn cropping system in South China. Communications in Soil Science and Plant Analysis, 39, 1583-1599.

[2] Granstedt, A., \& Kjellenberg, L. (1997). Long-term field experiment in Sweden: Effects of organic and inorganic fertilizers on soil fertility and crop quality. Proceedings of an International Conference in Boston, Tufts University, Agricultural Production and Nutrition, Massachusetts March.

[3] Lazcano, C., Gómez-Brandón, M., Revilla, P., \& Jorge Domínguez, J. (2013). Short-term effects of organic and inorganic fertilizers on soil microbial community structure and function - A field study with sweet corn. Biology and Fertility of Soils, 49, 723-733.

[4] Zublena, J. P., Baird, J. V., \& Lilly, J. P. (1991). Soil facts nutrient content of fertilizer and organic materials. North Carolina Cooperative Extension Service.

[5] Mitchell, C. C. (2008). Nutrient content of fertilizer materials. Alabama Cooperative Extension System.

[6] Disbunjatim. (2011). Potensi limbah bahan organic.

[7] Savant, N. K, Korndorfer, G. H., Datnoff, L. E., \& Snyder, G. H. (1999). Silicon nutrition and sugarcane production: A review. Journal of Plant Nutrition, 22(12), 1853-1903.

[8] Schmutterer, H. (1990). Properties and potential of natural pesticides from the neem tree, AZADIRACHTAINDICA. Annual Review of Entomology, 35, 271-297.

[9] Brotodjojo, R. R. R. (2014). Pengaruh konsentrasi ekstrak biji nimba terhadap biologi Plutella xylostella L. di laboratorium. Agrivet, 18, 23-28.

[10] Supriyatin. (2000). Pemanfaatanmimba (Azadirachtaindica) untukmengendalikan cylasformicariuspadaubijalar. Prosiding Seminar Teknologi Pertanian Spesifik Lokasi Dalam Upaya Peningkatan Kesejahteraan Petanidan Pelestarian Lingkungan. Instalasi Penelitiandan Pengkajian Teknologi Pertanian, Yogyakarta.

[11] Kraiss, H., \& Cullen, E. M. (2008). Insect growth regulator effects of azadirachtin and neem oil on survivorship, development and fecundity of Aphis glycines (Homoptera: Aphididae) and its predator, Harmonia axyridis (Coleoptera: Coccinellidae). Pest Management Science, 64(6), 660-668.

[12] Lokanadhan, S., Muthukrishnan, P., \& Jeyaraman, S. (2012). Neem products and their agricultural 
applications. Journal of Biopesticides, 5, 72-76.

[13] Achio, S., Ameko, E., Kutsanedzie, F., \& Alhassan, S. (2012). Paper Insecticidal effects of various neem preparations against some insects of agricultural and public health concern. International Journal of Research in BioSciences, 1(2), 11-19.

[14] Grainge, M., \& Ahmad. (1988). Handbook of Plant with Pest-Control Properties. Wiley-Interscience, New York.

[15] Blaney, W. M., \& Simmonds, M. S. J. (1995). Feeding behaviour. The Neem Tree (pp.171-176). VCH Verlagsgesellschaffmb H. Weinhim.

[16] Mordue, A. J., \& Nisbet, A. J. (2000). Azadirachtin from the neem tree, Azadirachta indica: Its action against insects. Anais da Sociedade Entomológica do Brasil, 29(4), 615-632.

[17] Anonymous. (2006). Fighting a sugarcane pest with silicon applications.

[18] Sumida, H. (2002). Plant Available silicon in paddy soil. National Agricultural Research Center for Tohoku Region Omagari.

[19] Morales, H., Perfecto, I., \& Ferguson, B. (2001). Traditional fertilization and its effect on corn insect populations in the Guatemalan highlands. Agriculture, Ecosystems \& Environment, 84, 145-155.

[20] Emden, H. F. (1966). Studies on the relations of insect and host plant. III. A comparison of the reproduction of Brevicorynebrassicae and Myzuspersicae (Hemiptera: Aphididae) on Brussels sprout plants supplied with different rates of nitrogen and potassium. Entomologia Experimentaliset Applicata, 9, 444-460.

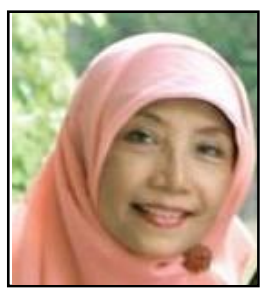

R. R. Rukmowati Brotodjojo graduated from Faculty of Agriculture, Gadjah Mada University, Indonesia with the bachelor degree in 1989. She majored in plant protection. She got her master degree in agricultural entomology from the University of Sydney, Australia in 1998 and obtained her $\mathrm{PhD}$ in the same field from the University of Queensland, Australia in 2007.

She works as a lecturer in the Faculty of Agriculture, Universitas Pembangunan Nasional "Veteran" Yogyakarta (UPNVY), Indonesia since 1990. She is a member of Curriculum Review Team at the Faculty of Agriculture, UPNVY. She is assigned as the head of Office of International Affairs UPNVY since 2013 until now. She teaches Introductory to Agriculture, Fundamentals of Plant Protection, Plant Pathology and Pest Management. Her research interest is in the area of plant protection, especially related to biological control and sustainable agriculture.

Dr. R. R. Rukmowati Brotodjojo is a member of the International Societies of Sugar Cane Technologist, and the Entomological Society of Indonesia. She got Endeavour Award as a research fellow from the Department of Education, Employments and Workplace Relations, Australia in 2009. She awarded as An Outstanding Lecturer from UPNVY in 2010.

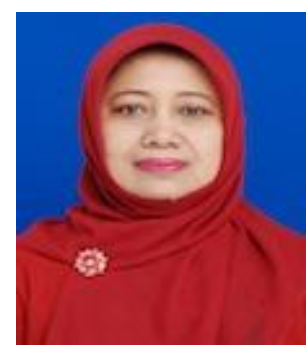

Dyah Arbiwati graduated from Faculty of Agriculture, Universitas Pembangunan Nasional "Veteran" Yogyakarta (UPNVY), Indonesia with the bachelor degree in 1988. She majored in soil sciences. She got her master DEGREE in soil sciences from Gadjah Mada University, Indonesia in 2000.

She works as a lecturer in the Faculty of Agriculture, Universitas Pembangunan Nasional "Veteran" Yogyakarta (UPNVY), Indonesia since 1989. She teaches fertilizer technology, soil fertility and health, introductory to soil sciences, soil and water conservation. Her research interest is on management and improvement of soil fertility. Mrs. DyahArbiwati is a member of The Indonesian Society of Soil Science. 